\title{
THE EFFECT OF LEAN HOSPITAL APPLICATION ON NURSE SATISFACTION AND PERFORMANCE AT PKU MUHAMMADIYAH HOSPITAL, DELANGGU, CENTRAL JAVA
}

\author{
Naviatullaily Yarsiska, Sagiran, Nur Hidayah \\ Masters Program in Hospital Management, Universitas Muhammadiyah Yogyakarta
}

\begin{abstract}
Background: Healthcare systems are facing growing challenges. In response to this challenge, healthcare providers are striving to improve outcomes while simultaneously achieving greater efficiency. One prominent improvement method is the Lean management system. Lean hospital is the methods to improve the mentality of patients and reduce treatment error and infection. This study aimed to examine the effect of Lean hospital application on nurse satisfaction and performance at PKU Muhammadiyah Hospital, Delanggu, Central Java.

Subjects and Method: This was a cross-sectional study conducted at PKU Muhammadiyah Hospital, Delanggu, Yogyakarta. A total of 130 patients was selected for this study by total sampling. The dependent variables were satisfaction and nurse performance. The independent variable was Lean hospital application. The data were obtained from a set of questionnaire. The hypothetical model was tested using structural equation model.

Results: The application of Lean hospital directly increased nurse satisfaction $(b=$ 5.79; $\mathrm{p}=0.011)$. Lean hospital application also directly increased nurse performance, although it was not statistically significant $(b=2.26 ; p=0.197)$. Nurse satisfaction increased nurse performance $(b=13.27 ; p=0.023)$.

Conclusion: The application of Lean hospital has direct positive effects on both nurse satisfaction and nurse performance. Nurse satisfaction affects nurse performance.
\end{abstract}

Keywords: Lean hospital, nurse satisfaction, nurse performance

\section{Correspondence:}

Naviatullaily Yarsiska. Masters Program in Hospital Management, Universitas Muhammadiyah Yogyakarta, Indonesia. Email: naviatullaily@yahoo.com Mobile: 08179244088. 